\title{
What conditions supply chain strategies of ports? The case of Dubai
}

\author{
Wouter Jacobs $\cdot$ Peter V. Hall
}

Published online: 4 July 2007

(C) Springer Science+Business Media B.V. 2007

\begin{abstract}
Recent academic debates about port competition have centered on the strategic responses of port authorities, operators, managers and owners to the emergence of global supply chains. The competitive performance of a port authority or operator, given the rise of the integrated logistics sector, depends increasingly on its strategic relationship to these supply chains and rather less on traditional port competition factors such as hinterland size and physical infrastructure. However, there are few empirical studies investigating the degree to which particular port actors are capable of inserting themselves into global supply chains. In this article we ask what factors condition the supply chain strategies of port actors. We hypothesize that the strategic supply chain choices of a port authority or operator are conditioned by the territorialized institutional framework in which the dominant actors in a port operate. We apply these insights through a case study of the transformation of Dubai Port Authority, and the rise of Dubai Ports World (DPW).
\end{abstract}

W. Jacobs $(\bowtie)$

Department of Applied Economics, Erasmus University Rotterdam, Burgemeester Oudlaan 50, P.O. Box 1738,

Rotterdam 3000 DR, The Netherlands

e-mail:wjacobs@few.eur.nl

\section{P. V. Hall}

Urban Studies Program, Simon Fraser University, 515 West Hastings Street, Vancouver, BC V6B5K3, Canada e-mail: pvhall@sfu.ca
Keywords Supply chains - Strategy · Dubai · Ports · Structure of provision

\section{Introduction}

The rise of global production networks (GPN) has been accompanied by the emergence of a new class of actor on the global economic stage, the global transportation and logistics operating firm (Dicken 2003). By virtue of their power to organize, coordinate and even shape distribution systems that link sites of global production and consumption, these airlines, shipping lines, logistics providers and other actors are attracting considerable interest among economic and transportation geographers (Hall et al. 2006; Hesse and Rodrigue 2006). One place where the power, influence and limitations of the new class of global actors are clearly on display is in the world's seaports where we observe a shift of responsibilities from public port authorities to privately owned global terminal operators (Olivier and Slack 2006; Slack and Frémont 2005). However, some of the largest global terminal operators, most notably Dubai Ports World (DPW) and the Port of Singapore Authority (now PSA Corporation) began life as public port authorities. Unlike carriers such as Maersk which have their own terminal operating subsidiaries, these actors have pursued an aggressive strategy of horizontal integration, merging, acquiring 
and leasing port terminals well beyond their home base.

How are we to understand the rise of these formerly place-bound public authorities, and the factors that lie behind their successful global reach? Recent academic debate on port strategy has centered on the emergence of global supply chains (Robinson 2002) and associated changes in the organization and governance of the maritime logistical sector (Slack 2004; Notteboom 2004; World Bank 2001). Shipping lines, private terminal operators and land-based hinterland transporters have horizontally and vertically integrated their operations and services through strategic alignments, corporate takeovers and application of new technologies. In some cases, the bargaining power of these newly integrated players, in terms of tariffs, terminal lease concessions and service provision, has enhanced considerably vis-àvis the public port authorities that control development rights within the port area but that are themselves constrained by their physical immobility and political accountability to the public. We have also witnessed a process of market maturation with the entry of new private container ports and port operators.

What are the consequences for the competitive strategies of port authorities and operators? As argued by Robinson (2002), a port in the contemporary world has to be understood as a location where third party logistical service providers generate, share and compete over value with other players within the supply chain. Consequently, the port authority or operator's competitive strategic advantage is not only based upon operational efficiency or location, but increasingly on the degree to which it is embedded in supply chains, is able to enhance the efficiencies within these supply chains, and is able to extract value from them. However, to date there has been very little empirical research on what lies behind the capability of some port operators to become successful global supply chain actors.

We argue that ports are territorially embedded in a historically path dependent and contingent institutional framework. This framework constitutes the context for strategic action (cf Storper 1997) by a variety of port actors, including shippers, carriers, port operators and public authorities. In turn, as these actors provide critical logistical services, ports become sites at which global supply chains may become territorially embedded. Our hypothesis is that the nature of the territorial relations of the port conditions the supply chain strategy of key or dominant port actors, and consequently the port's ability to become embedded in global supply chains.

In making this argument, we follow the relational perspective of Henderson et al. (2002) who recognize that Global Production Networks (GPN) are not merely located in particular places. Instead, GPNs become territorially embedded in the sense that they are enabled and/or constrained by the prevailing economic activities and social dynamics that already exits in those places: "From a development point of view, then, the mode of territorial embeddedness or the degree of a GPN firm's commitment to a particular location is an important factor for value creation, enhancement and capture" (Henderson et al. 2002, p.459). Thus, this argument turns on a two-way interaction: at the same time that key port actors as territorialized service providers need to embed themselves into supply chains in order to safeguard and strengthen their competitive positions, 'footloose' firms operating in supply chains need to be sensitive about the implications for value creation of the territorialized institutional structure of ports within which they become embedded. This paper makes a first attempt to explore this relationship by focusing on Dubai Ports and the transformation of its public port authority into a transnational terminal operator.

The paper is structured as follows. In the next section we focus on the general debate about the embeddedness of ports within supply chains and what this implies for port strategies. In the third section we construct a model to investigate these port strategies within the territorially and institutionally embedded structures in which ports operate by making use of the structure of provision approach (SOP) (Jacobs 2007b). The conceptual model is then applied to the case of Dubai.

In the period between February and May 2005, the lead author conducted over 15 in depth interviews with port and government officials in Dubai and Khor Fakkan as well as with port users. Respondents were identified through desk top research using a snowball sampling technique, and additional interviews were conducted until the researcher was confident that he was not learning new or contradictory information. In addition to the primary interviews, data was gathered 
from reviewing strategy and planning documents, as well as the port's quarterly magazine. Our analysis sought to reconstruct the story of Dubai's global engagement by triangulation across the various data sources.

\section{Ports and supply chain strategies}

What do port actors, including public port authorities and terminal operators, want to achieve with respect to supply chains? Hall and Robbins (2007) make a distinction between insertion, integration and dominance as strategic goals of port authorities and operators, carriers, and other supply chain services providers. These goals may be viewed as the logistics sector analogues of the wider regional development goals of value creation, enhancement and capture discussed by Coe et al. (2004). ${ }^{1}$ However we do not use their terms because we are reluctant to assume that logistics sector actors are necessarily always engaged in the wider regional development process as commonly understood by economic geographers. For instance, while efficient logistics services (i.e. integration) may be a vital part of the strategic coupling process described by Coe et al., this process can also facilitate flows that bypass or even displace local economic actors. In other words, we choose to limit the meaning that we attach to the supply chain strategies of port authorities and operators because we recognize that their actions are not necessarily beneficial for regional economic development. In what follows, we discuss each of the goals in turn, noting that these goals are often closely inter-related and mutually reinforcing. Thus, a port actor may pursue more than one of these goals at a time.

\footnotetext{
${ }^{1}$ In turn, Coe et al (2004) are drawing on Kaplinsky's (1998) notion of value as economic rent, which Kaplinsky (2005) has defined elsewhere as follows: "Rent describes a situation where the parties who control a particular set of resources are able to gain from scarcity by insulating themselves from competition. This is achieved by taking advantage of or by creating barriers to entry of competitors" (62). Constructing barriers to entry is central to the supply chain strategies of insertion, integration and domination. Routing a flow through one port as opposed to another to generate back-haul savings (insertion), achieving virtual integration through data sharing (integration), or securing exclusive use of a marine terminal (domination) are all examples of actions that establish barriers to entry in the logistics sector.
}

First, port actors seek to insert themselves in supply chains as it provides them with access to critical resources such as technology, markets, capital, knowledge and expertise. In one sense, being inserted into one or more supply chain is the necessary precondition for a port (or any transportation hub) to become a site of economic activity; however, insertion has become a more complex and unstable goal for ports that find themselves in competition with each other to serve the same GPNs and hinterland territories. Over the years, port authorities and operators have pursued the goal of insertion by improving their landside connections; by offering financial incentives (e.g. customized reductions on tariffs) and lease concessions (e.g. dedicated terminals) to attract more shipping lines and port calls; and by networking with other ports and setting up regional trade offices (Notteboom and Winkelmans 2001).

Second, actors that are inserted in supply chains may seek to integrate activities within the supply chains in order to reduce overall transaction costs and provide services more efficiently. One reason why shipping lines have recently been engaged in vertical and horizontal integration strategies which effectively extend their control within the logistic chain, is so that they can reduce uncertainty, transactions and transport costs (Notteboom and Winkelmans 2001; Slack et al. 2002). One role for port authorities is to contribute to cost reduction for actors operating in logistical chains. They can do so in a number of ways. They can set up digital information systems that provide cheap, reliable and easily accessible operational information to port users. Port authorities can offer inter-modal transfer possibilities. Through effective land use planning they can stimulate the development of clusters, which in turn fosters learning, innovating and harmonizing processes among port users (de Langen 2003).

Third, actors operating in supply chains seek dominance, that is, the ability or power to extract value from logistics activities on a sustained basis. To some degree all actors within a supply chain are in competition with each other over the extraction and capture of value created by logistical operations (Cox et al. 2002). One strategy for dominance is to secure control over a scarce competency or asset such as the ability to handle niche cargo; exploiting economies of scale is another strategy for many transportation 
actors in the container/intermodal age. However, these resource-based dominance strategies are necessary but not sufficient for the sustained extraction of value. Here we employ a relational notion of power, in which power is defined as "the capacity to exercise that is realized only through the process of exercising" (Dicken et al. 2001, p. 93). This implies that dominance or power in a supply chain is both a position relative to others and to key resources, as well as a set of practices with regards to those relationships and resources. To illustrate this point, we might say that Maersk's dominance amongst container lines is not only about having the biggest ships; it is also about deploying these ships strategically to secure dredging and other concessions.

Using very different language, Heaver et al. (2000, p. 364) have observed precisely this behaviour in the shipping industry: "[T]here appears to be a strong economic incentive to acquire direct control over an ever larger part of the logistical chain". Vertical and horizontal integration by shipping lines and terminal operators have de facto increased their control over the logistical chain and, as such, their bargaining power vis-à-vis the port authorities and other place bound actors. This makes established ports reconsider their services, overall capacity, property rights arrangements, pricing policies and hinterland connections. In the case of Dubai, this reconsideration has led to the extension an aggressive dominance strategy from the regional to the global scale.

A complicating factor in global supply chain strategies of port actors is spatial scale (Hall and Robbins 2007). We can not reduce the spatial dimension in a simple global-local dichotomy since port actors are subject to a path dependent and place specific institutional framework (Stevens 1997; Hall 2003; Slack and Frémont 2005) that is both constraining and enabling. This implies that we need to be sensitive to the spatial organization of the state, the competencies of its agencies as well as the set of formal rules which structure the interaction between public and private agents.

The embeddedness of ports and supply chains

In order to develop a theoretical understanding of the factors that condition the supply chain strategies of ports, we first need to conceptualize supply chains themselves. Drawing on recent economic geography literature, we make use of the Global production network-perspective (cf. Henderson et al. 2002; Coe et al. 2004). Global production networks (GPN) can be defined as the globally organized nexus of interconnected functions and operations through which goods and services are produced, distributed and consumed. They are constructed and transformed over time by public, private or collective agents with asymmetrical positions of influence and power at different spatial scales. Firms operating in GPNs are characterized by their links with other members of the GPN regardless of their country of origin or local anchoring. The durability and stability of these formal and informal relationships determines the actor's individual network embeddedness as well as the structure and evolution of GPN as a whole. Network embeddedness involves inter-firm relationships as well as the relationships between firms and governmental agents at different spatial scales.

GPNs do not simply locate themselves in a particular place. Rather, they have histories of origin that condition their global expansion, and once a firm physically locates itself in another place, it is enabled and constrained by the economic activities and socio-cultural dynamics that already exist in that place. In other words, firms and GPNs are constantly becoming territorially embedded. Territorial embeddedness considers the extent to which an actor is anchored in particular territories or places. This embeddedness will manifest itself physically, institutionally and politically.

Actors become physically embedded through their investments in the built environment (e.g. lease concession, investments in superstructure) and also through their engagement with local resources and actors, including labour. Institutionally, actors become embedded through a set of formal rules and social relations that exist at a certain place and which enable and constrain them in their actions. Politically, the territorial embeddedness of actors manifests itself in the governance structure in which decisions over the allocation of resources and distribution of wealth are contested and negotiated. In order to investigate the territorial embeddedness of key or dominant actors in ports and their supply chain strategies, we make use of the structure of provision approach (SOP) as applied to ports (cf. Jacobs 2007b). 


\section{Structure of port provision}

The SOP was initially developed to investigate the political economy of the British housing market (Ball 1983), but can be applied to virtually any form of the built environment (Ball 1998; Gore and Nicholson 1991). A structure of provision refers to a network of social relationships, institutions and organizations, associated with the provision of particular types of building at specific points in time and space. 'Provision' encompasses the development, construction, ownership and use of land and buildings.

When we apply the SOP to ports, the focus is thus concerned with the interaction between organizations and institutions involved in the provision of a specific port's land, infrastructure and superstructure (e.g. cranes, storage facilities, gates, fork-trucks). For analytical reasons we distinguish three categories in the structure of provision which in reality are closely inter-related. $^{2}$ The first category refers to the actual physical condition of the ports, i.e. the quality of the port's infrastructure, superstructure and development potential on the port's land. The second category relates to institutional arrangements which regulate the use, ownership and development of port land and the infra/superstructure. Here we include property rights, land use planning, port tariffs, environmental and safety/security stipulations. The third category concerns the way port governance is structured, referring to the division of responsibilities between the public and private sector and between the different administrative-territorial levels of the state. Port governance structures play a key role in the way these institutions and organizations interact in the provision of the physical attributes of the port (Jacobs 2007b).

A structure of provision is not static, but is the subject of continual path dependent change due to market pressures, technological innovations, policies and other strategies of the organizations involved (cf. Ball 1998). It is here where we bring in the supply

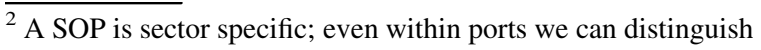
different SOPs, depending on the economic activity under study. Clearly, the dynamics of the container sector differ with the dynamics in the bulk-sector or the automotive-sector, which corresponds with different types of firms and interests, with different demands for the built environment and for the ports' institutional arrangements. In this article we focus on the container sector.
}

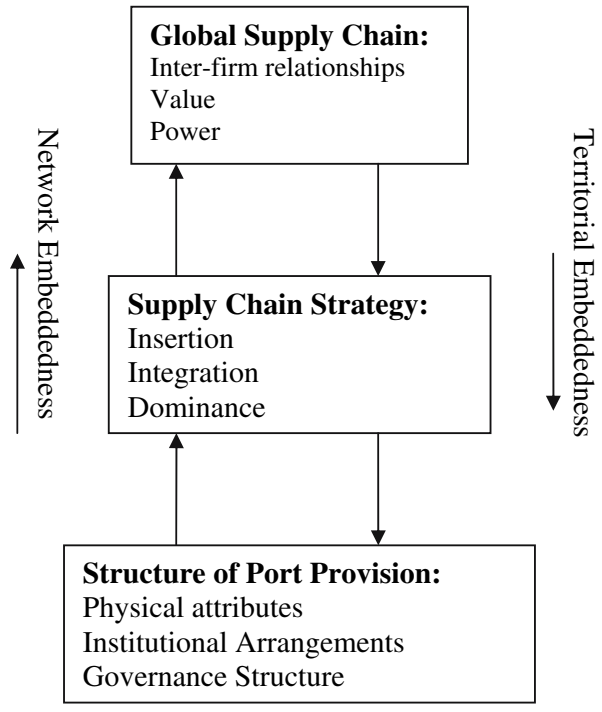

Fig. 1 The embeddedness of ports and global supply chains

chain strategies of insertion, integration and dominance into our model (see Fig. 1). Actors use these strategies as they seek to become embedded within global supply chains and production networks. Global supply chains are characterized by particular constellations of inter-firm and public-private relationships (e.g. contractual agreements, corporate ties, alignments, cartels) that define the market landscape in which actors compete and in which they hold asymmetrical power positions. However, actors operating in supply chains at the same time become territorially embedded in a particular port's SOP, for example, by acquiring a dedicated terminal concession. Once territorially embedded, these players become more or less dependent on the port's development and policies for their own competitive position within the supply chain.

What dimensions of the SOP provide more freedom of action for port actors to successfully engage in supply chain strategies and to become firmly embedded within these GPNs? In one case the SOP might enable actors to pursue aggressive supply chain strategies that might facilitate their 'global' expansion, whereas in another case the SOP may constrain such actions. Here it is important that we do not view the various categories of the SOP in isolation since they are closely inter-related. Obviously the physical attributes of the port are an important factor influencing insertion into a given 
supply chain. Without the appropriate infra-and superstructure and sufficient capacity, or a suitable location, no port will be able to attract cargo flows on a sustainable basis. However, network embeddedness is not only achieved by providing the right physical conditions, but also needs to be supported by institutional arrangements and governance structures which, in turn, allows for further integration of the port in the supply chain. In this respect, the ownership and user rights of the port's physical attributes are of strategic importance, as are any regulatory constraints on whether operators can engage in 'strategic pricing' or provide financial incentives to customers.

Here, the degree of competition within the port and between ports in the region is particularly relevant. Wherever intra-port competition is limited, a port operator can, in theory, extract monopoly-rents (de Langen and Pallis 2006) and acquire superprofits. The ability to do so depends on the degree to which an operator has full ownership over the port's physical resources and the degree to which it is constrained by regulatory bodies, such as the port authority or other state agencies. Limited intra-port competition is also likely to imply a more consolidated governance structure and lower costs associated with coordination and conflict-resolving mechanisms among port users. Increased competition between ports within the region can prevent intra-port monopolists from acquiring super-profits, even if high barriers to entry to the monopolist's port remain (cf. Notteboom 2002). However, increased inter-port competition and limited intra-port competition might also lead an intra-port monopolist to seek to extract rents from the public sector and immobile port users through strategic pricing, especially when it has preferential access to capital or when it does not face any institutional constraints or political opposition through the governance system.

In that respect, we need to take into account the role of the public sector and its commitment and support to the port's development and management. In physical terms, the state can subsidize port development directly by, for example, financing port expansion projects or the improvement of hinterland connections, or indirectly by, for example, offering favorable conditions under which a port can borrow money from the state for strategic investments. As the rule-making and enforcing agent, the state can offer favorable institutional conditions for port operators to compete and engage in supply chain strategies in a number of ways by, for example, setting high regulatory barriers to market entry for foreign companies within the port, through shareholding in port authorities or through direct ownership of the physical attributes of the port. These latter aspects are directly related to the governance dimension of the SOP. The way the state provides material or institutional support to ports depends on the history of the ports, their contribution to the economy (in terms of jobs and revenues), and the structure of the state itself (Brooks and Cullinane 2006; Jacobs 2007a).

As such, the SOP acts to create strategic opportunities by which global operating firms may become territorially embedded within a port and, in so doing, can capture the value created in particular geographic location. At the same time the SOP also acts to create strategic opportunities for locally based and port dependent actors to attach to, and become embedded within, particular GPNs. The relationship between GPNs and SOPs is thus that they are mutually constituting and co-evolving. How this strategic game plays out in particular places remains an empirical question, and in turning to specific cases, we should be aware of contingent factors such as regional context and history, the scalar structure of the state, timing and perhaps even pure luck. The remainder of this paper examines these relationships in more detail in Dubai.

\section{The case of Dubai ports}

Dubai is a fast growing city-state of 1.2 million inhabitants, located at the Arabian Gulf. ${ }^{3}$ It is one of the seven United Arab Emirates, ${ }^{4}$ a federation founded in 1971 when the British abandoned this imperial outpost. Though the discovery of oil in 1968 definitely contributed to Dubai's initial economic and urban growth, the contribution of oil to local GDP in 2006 was less than $10 \%$ and still declining. Over the last 20 years Dubai has strategically re-invested oil

\footnotetext{
${ }^{3}$ In the western world, the Arabian Gulf is often named the Persian Gulf. We use both names interchangeably.

${ }^{4}$ The Federation of the United Arab Emirates consists of the capital Abu Dhabi, Dubai, Sharjah, Ras al Khaimah, Ajman, Umm al Quwain and Fujairah.
} 
revenue in the diversification of its economy and by doing so, reduced its dependency on the oil-sector (Jacobs 2005). Its twin seaports (Jebel Ali and Port Rashid) and airport have been the cornerstones of this development strategy (Broeze 1999).

Today, Dubai is the Middle East's main transportation hub $^{5}$ (see Table 1), a position which it consolidated in recent years. This is despite the fact that new regional competitors emerged in the 1990s, most notably Salalah, Khor Fakkan, and Aden. These ports at the Arabian Sea enjoy a geographical advantage over Dubai. For instance, transit through the Straits of Hormuz means that it takes a vessel $24 \mathrm{~h}$ longer to reach Dubai than Khor Fakkan (see Fig. 2). Major port improvements in India and Pakistan also started to pose threats to Dubai's position as major transhipment hub for the Subcontinent. More significantly, these new facilities were partly developed and operated by established private players in terminal operations: APM-Maersk in Salalah, PSA in Aden, and P\&O Ports in Nheva Sheva (Mumbai) and Port Qasim (Karachi). In order to understand how Dubai has developed into the region's main hub and how it countered these competitive threats, we need to take into account the territorial embeddedness of Dubai Ports as conceptualized in Fig. 1. We begin this section by discussing the physical, institutional and governance dimensions of Dubai's structure of provision, before showing how this framework has provided the context for Dubai's successful supply chain strategies since 1990.

\section{The nature of territorial embeddedness of Dubai ports}

Physical conditions

As regards the physical conditions, both Dubai Ports are able to compete successfully against regional competitors which enjoy more favourable geographic locations by offering superior facilities: “DPA's

\footnotetext{
5 The Middle East is serviced with direct port calls at the Gulf and the Red Sea, where the ports of Dubai and Jeddah act as hub for intra-regional feeder services. Because of the lack of competitive infrastructure, the Indian Subcontinent also acts as the extended hinterland of the Gulf ports for the ocean-carriers. Historically, Colombo has also played a strong role as transhipment hub for this market (cf. Drewry 2000).
}

[Dubai Ports Authority] success has been built on solid foundations, which include a state-of-the-art infrastructure and superstructure, a slick marketing machine and a professional service" (Drewry 2000, p. 100). The container terminals at Jebel Ali and Port Rashid are 1,150,800 and 689,400 square meters respectively. Control of all the port land ultimately lies in the hands of the Emir or ruler of Dubai who has gifted the freehold to DPA. At the time of writing, port land is not available for lease to third parties. The depth of the main channel of Jebel Ali is $17 \mathrm{~m}$ and the width is $320 \mathrm{~m}$. Port Rashid's main channel has a width of $190 \mathrm{~m}$ and a minimum depth of $13 \mathrm{~m}$. DPA also owns the superstructure at both ports. Port Rashid has seven Panamax cranes. At Jebel Ali DPA deploys 23 cranes of which 11 are super post Panamax cranes, allowing DPA to handle the biggest carriers in the business. Within the ports of Dubai, DPA has a monopoly with no intra-port competition from other terminal operators. This exclusive position in terms of container terminal operations within Jebel Ali port has however been not unproblematic given the increased demand by shipping lines for dedicated terminals: "[d]uring 1999 the DPA confirmed that $25-30 \%$ of its Maersk-Sealand transhipment business has been lost to Salalah."(Drewry 2000, p. 18). These developments pose questions as to what degree DPA will be able maintain its monopoly at Jebel Ali.

An integral part of Jebel Ali port is the Jebel Ali Free Zone (see Fig. 3). In 1991 over 300 companies (DPA 1992) were located in the Free Zone. ${ }^{6}$ The Zone currently hosts 3,880 businesses originating from over 100 countries of which $39 \%$ come from the Middle East region, 29\% from Asia, 20\% from Europe and $7 \%$ from the Americas. The planned development of nearby Jebel Ali International Airport, will provide opportunities for sea-air modal shifts and further strengthen the port-industrial cluster.

\footnotetext{
${ }^{6}$ There are in fact several Free Zones in Dubai that act as clusters since they are entirely dedicated to specific types of business activity, for example Dubai Media City, Dubai Knowledge Village, Dubai Internet City. Also the major housing projects (the Palms, the World) are designated as Free Zones.
} 
Table 1 Regional ports throughput (TEU) and market share (\%)

\begin{tabular}{|c|c|c|c|c|c|c|}
\hline & 2000 & 2001 & 2002 & 2003 & 2004 & 2005 \\
\hline \multicolumn{7}{|l|}{ Gulf ports (country) ${ }^{\mathrm{a}}$} \\
\hline Dubai ports $(\mathrm{UAE})^{\mathrm{b}}$ & $3,058,868$ & $3,501,820$ & $4,194,265$ & $5,151,956$ & $6,428,883$ & $7,619,222$ \\
\hline Market share $(\%)$ & 27 & 28 & 29 & 29 & 30 & 33 \\
\hline Khor Fakkan (UAE) & $1,014,122$ & $1,089,866$ & $1,266,131$ & $1,449,451$ & $1,819,431$ & $1,929,729$ \\
\hline Market share $(\%)$ & 9 & 9 & 9 & 8 & 9 & 8 \\
\hline Other UAE-ports ${ }^{\mathrm{c}}$ & 982,793 & 666,973 & 647,426 & 587,581 & 652,318 & $291,700^{\mathrm{d}}$ \\
\hline Market share $(\%)$ & 9 & 5 & 4 & 3 & 3 & 1 \\
\hline Dammam (KSA) & 454,640 & 489,544 & 563,149 & 634,976 & 743,457 & 894,809 \\
\hline Market share $(\%)$ & 4 & 4 & 4 & 4 & 3 & 4 \\
\hline Mina Sulman (Bahr.) & 132,100 & 140,144 & 155,037 & 175,688 & 193,731 & N.A. \\
\hline Market share $(\%)$ & 1 & 1 & 1 & 1 & 1 & \\
\hline Bandar Abbas (Iran) & 415,382 & 548,000 & 731,000 & 965,011 & $1,142,659$ & $1,265,000$ \\
\hline Market share $(\%)$ & 4 & 4 & 5 & 5 & 5 & 5 \\
\hline \multicolumn{7}{|c|}{ Other regional ports (country) } \\
\hline Jeddah (KSA) & $1,043,617$ & $1,180,427$ & $1,366,902$ & $1,763,865$ & $2,425,930$ & $2,860,000$ \\
\hline Market share $(\%)$ & 9 & 9 & 9 & 10 & 11 & 12 \\
\hline Salalah (Oman) & $1,032,692$ & $1,187,753$ & $1,211,634$ & $2,001,259$ & $2,228,546$ & $2,491,741$ \\
\hline Market share $(\%)$ & 9 & 9 & 8 & 11 & 10 & 11 \\
\hline Port Qaboos (Oman) & 128,857 & 143,933 & 203,864 & 264,826 & 286,810 & N.A. \\
\hline Market share $(\%)$ & 1 & 1 & 1 & 1 & 1 & \\
\hline Colombo (Sri Lanka) & $1,732,855$ & $1,726,605$ & $1,764,717$ & $1,959,336$ & $2,220,573$ & $2,455,329$ \\
\hline Market share $(\%)$ & 15 & 14 & 12 & 11 & 10 & 11 \\
\hline Nheva Sheva (India) & $1,124,723$ & $1,462,000$ & $1,850,000$ & $2,174,098$ & $2,361,000$ & $2,568,000$ \\
\hline Market share $(\%)$ & 10 & 12 & 13 & 12 & 11 & 11 \\
\hline Port Qasim (Pakistan) & N.A. & 172,000 & 289,000 & 419,000 & 519,000 & 585,000 \\
\hline Market share $(\%)$ & & 1 & 2 & 2 & 2 & 3 \\
\hline Aden (Yemen) & 248,112 & 377,708 & 398,981 & 156,151 & 318,901 & 317,897 \\
\hline Market share $(\%)$ & 2 & 3 & 3 & 1 & 1 & 1 \\
\hline
\end{tabular}

${ }^{a}$ Does not include ports of Shuwaikh and Shuaibah (Kuwait), Umm Qasr (Iraq), Jubail (KSA), Bandar Khoumeini (Iran) due to lack of data. The Kuwaiti Ports combined had a throughput of 333,097 TEU in 2001 equivalent to a market share of $2 \%$ or $3 \%$

b Jebel Ali + Port Rashid

c Includes Port Zayed (Abu Dhabi), Port of Fujairah (Fujairah) and Port Khalid (Sharjah)

d Excludes the throughput of Port Khalid

Source: Provided by DPA (2005), verified by authors

Institutional arrangements

Dubai Ports can be best understood as a public service port (Stevens 1997; World Bank 2001), since all the land, infra-and super-structure are in hands of DPA. As the state agency in charge of Dubai Ports and its terminal operations, DPA decides on the port dues and the terminal tariffs. The port dues are levied on all vessels entering the port, apart from those exempted by the ruler of Dubai. For vessels moving between Port Rashid and Jebel Ali, port dues are assessed as if the vessel had made only one continuous Dubai Port stay. DPA also applies a so-called Port Receiving Charge (PRC) against loaded and empty containers and bulk cargo trailers entering or exiting port property from the landside via non-Dubai Ports. The PRC is also levied on containers which have stayed outside port custody for a period of more than 20 days. This is to discourage the trucking of containers to Dubai from other ports in the region. 


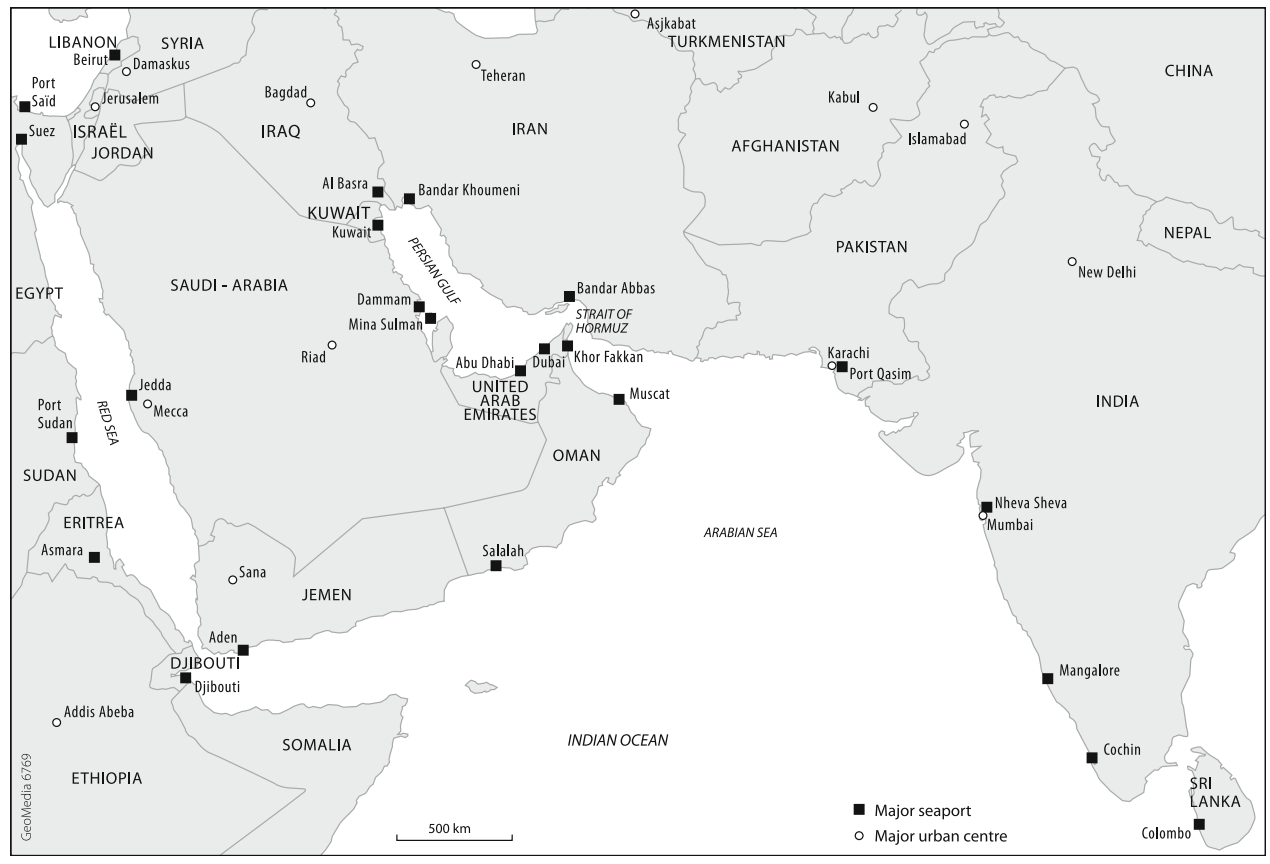

Fig. 2 The major ports in the Greater Middle East. Source: Jacobs (2007a)

Through its tariff, DPA can provide strategic financial incentives to attract shipping lines and their containers. Empty and transhipment containers have a free storage time of 20 days; import and export containers have 10 days free storage time. Containers subject to PRC are exempted from the limits on free storage time. More importantly, DPA provides considerable discounts on the terminal tariffs to shipping lines that guarantee at least 18,000 full container (over 20 feet) moves per year, with more generous discounts available at higher thresholds up to 80,000 full container moves per year (see DPA Port Tariff, section D 2006). When a shipping line can guarantee more than 80,000 moves per year it receives a $48 \%$ discount on the terminal tariffs for every move beyond that level. These discounts allow shipping lines to capture value by reducing operating costs or lowering their prices.

The institutional arrangements at the Jebel Ali Free Zone also confer competitive supply chain advantages. Full foreign share ownership is allowed inside the Free Zone, whereas only $49 \%$ foreign share ownership is allowed outside the Free Zone. Land, offices and pre-fabricated industrial units within the Free Zone are available for various lease periods, with no freehold (fee simple or absolute) ownership allowed. The absence of freehold ownership apparently does not have any effect on the attraction of businesses. There are no corporate taxes, no personal income taxes, and $100 \%$ repatriation of capital and profits. There is no imposition of duties on imported or exported goods within the Free Zone, whereas outside the Free Zone custom duties are fixed at 5\% by the Gulf Cooperation Council. ${ }^{7}$ This latter arrangement also largely works to the advantage of Dubai since its ports act as the GCC's main point of entry for imports.

How can DPA finance these considerable discounts? One might wonder whether there is not some form of subsidy through the state's oil revenues. DPA senior managers insisted in interviews that there is no state subsidy involved and that DPA is a financially independent, if state-owned, commercial enterprise. No evidence of direct state subsidy in the form of money transfers from the government to DPA has been found. Indirectly, however, the state does

\footnotetext{
${ }^{7}$ The Gulf Cooperation Council consists of Kuwait, Bahrain, Qatar, Saudi Arabia, United Arab Emirates and Oman. They formed a customs union in 2003 with custom duties fixed at $5 \%$ and with single entry point arrangement for imported goods into the Union.
} 


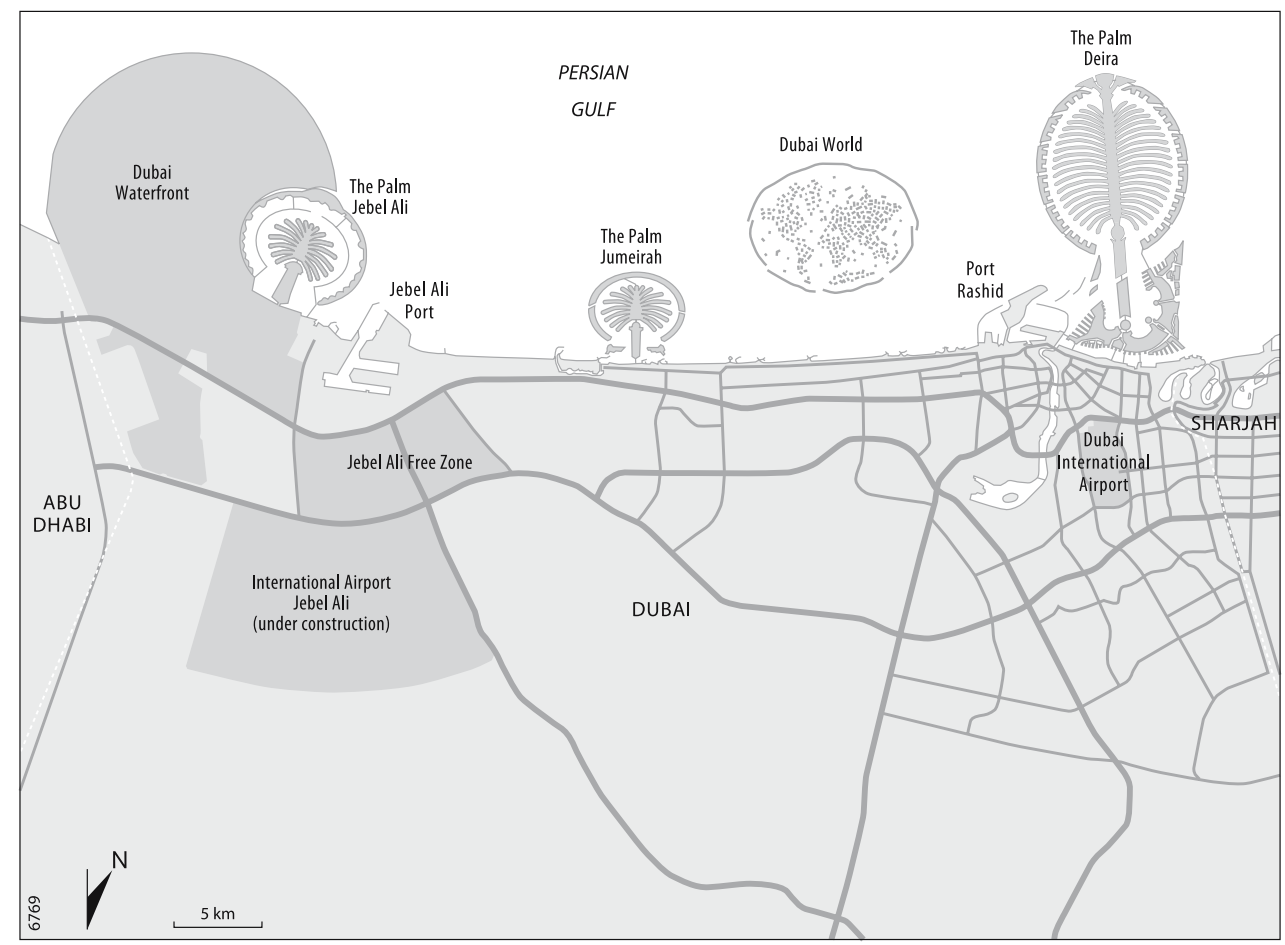

Fig. 3 Location of Dubai ports, Jebel Ali Free Zone and major urban projects. Source: Jacobs (2007a)

provide subsidy, e.g. through tax breaks for foreign firms locating in Dubai or by providing cheap energy to firms. Clearly, the construction of Port Rashid and Jebel Ali has been financed from oil-revenues, but most ports across the world have been developed with considerable financial support from their national governments. DPA is part of a larger conglomerate, the Port Customs \& Free Zone Corporation (PCFC) and, as we will see in the next section, PCFC includes a number of other divisions through which capital can be mobilized and transferred to DPA. It must be stated, however, that PCFC's actual financial position is not known since they do not publish any annual financial statements.

As regards labour costs and conditions, the salient point is that labour unions are not tolerated in the Emirate. As such, DPA can implement work and technological changes with relative ease as they face no union opposition. Stevedore labour is provided by the Dubai Labour Supply Company (Dulsco), a locally based limited liability company with strong government ties. Much of the unskilled and cheap labour is recruited in India and Pakistan and trained in Dubai. However, for such specialized operations (e.g. post Panamax crane drivers) no expenses are spared to recruit the best in the industry. Tough immigration laws and hiring-and-firing at will make the labour force extremely vulnerable and powerless. The costs of labour are approximately 125 Dhs./gang hour (equivalent to some 35 US\$/ gang hour), although much depends on the size of the gang.

As regards security, Dubai was the first port in the region to join the Container Security Initiative (CSI) in 2004, later to be followed by Salalah and Colombo. Currently, Dubai is the only port in the Gulf that is allowed to handle containers that are directly bound for the United States. This is a considerable competitive advantage over the other ports in a region troubled by various armed conflicts that ultimately result in higher insurance rates for shipping goods. Dubai and its ports also came out of the first Gulf War (1991-1992) relatively unharmed and to some degree took advantage of it. As DPA's Handbook of 1992 announces: "[A]s a result of the Gulf War, the Port Rashid Terminal became the distribution hub for a number of motor vehicle manufacturers" (DPA 1992, p. 33). 
According to sources within DPA, Dubai Ports was able to retain their customer base after the start of the Second Gulf War in 2003 in spite of the higher insurance rates for ships entering the Gulf. This is because DPA took upon full responsibility for all vessels bound for Dubai. By taking on this financial risky commitment, DPA ensured its growth even in a time of armed conflict. The second Gulf War has in fact brought in more transhipment cargo to Dubai, since Port Rashid has been dedicated almost entirely to the logistical supply of the Allied forces in Iraq and the transhipment of materials for the reconstruction.

\section{Governance structure}

An overriding institutional feature of Dubai is the strong corporatist leadership of the Emirate. The emir and ruler of Dubai and vice-president of the UAE, currently His Highness Sheikh Mohammed bin Rashid Al Maktoum, wields considerable decision-making power. He is surrounded by a small group of local elites (the Director-Generals) who are in charge of Dubai's governmental departments and the statecontrolled enterprises. The Director-General of the Ports Customs \& Free Zone Corporation (PCFC), Sultan Ahmed bin Sulayem, controls amongst other things, DPA and Jebel Ali Free Zone Authority (JAFZA) as well as the overall holding company Dubai World. He also appoints the members of the PCFC's board of directors. The current board is a mixture of local business leaders and former directors of CSX World Terminals, a result of the takeover by PCFC to be discussed later.

The dominance of the Al Maktoum Family is a central feature of the governance of the Dubai state. The Al Maktoum-clan ensures political support for its hereditary leadership and growth agenda by mobilizing the members of other locally based families into the state apparatus. As Davis (2006, p. 61) critically observed: "Feudal absolutism-the Maktoum dynasty owns the land area of Dubai-meanwhile has been spruced up as the last word in enlightened corporate administration, and the political sphere has been officially collapsed into the managerial". Notwithstanding this critique, governance arrangements do ensure swift decision-making over port development projects since there is virtually no political opposition from environmental or community pressure groups, or labour unions. The rulers of Dubai can therefore implement its economic growth agenda with relative ease. As such, the Emirate of Dubai can be best understood as an autocratic development state (Painter 2000), identified in places such as Singapore and Taiwan. It is thus not surprising that Dubai chose an aggressive and increasingly globally-oriented supply chain strategy when it began to face competition from other ports in the region in the 1990s.

\section{Dubai's supply chain strategy}

Insertion: Jebel Ali Port and Free Zone Cluster

The construction of Port Rashid located in Dubai City started in the 1960s and was accomplished in 1972. Not long after completion, the former emir Sheikh Rashid bin Saeed Al Maktoum launched another port development project at Jebel Ali. The first phase of the project was finished in 1979 and the project was completed in 1983. Together with the creation of the Jebel Ali Free Zone in 1985, Dubai had put in place the most modern infra- and superstructure in the region capable of handling the (post-) Panamax generation of ocean carriers. By successfully anticipating containerization, Dubai was able to participate in the continuous growth of trade and consumption in the region.

The Free Zone and the Port clearly have a symbiotic relationship. The Free Zone has ensured the Dubai port's focus on transhipment, and the proximity of the port has attracted numerous valueadded activities into the Free Zone. Almost twothirds of Dubai's trade volume is re-exported, with exporters and manufacturers benefiting from the tax-incentives in the Free Zone. Among the supply chains routed through the Free Zone are construction materials (e.g. steel, fibre optics, machine tools), automotive parts and vehicles, electronics, textiles, food and beverages. The typical value added activity includes the assembling, labelling and repackaging of goods that are produced in factories in India, China and Southeast Asia and destined for the European and North-American consumer markets. In addition, the Free Zone hosts the regional trade offices of such global consumer product manufacturers as Sony, General Electric, Philips, Honda, LG, Nokia, Pepsi Co to costeffectively distribute their brands and products to 
fast growing markets in the region. As such, the Jebel Ali 'Free Zone- port bundle' allows Dubai to "tap into global outsourcing trends and to insert themselves in the global production chain" (Wang and Olivier 2006, p. 1487) or as pointed out by one senior Arab industry commentator: "Clearly, the success of Jebel Ali as a port is based less on Dubai's domestic growth than on its ability to handle transhipment bound for India, Iraq, Iran and the wider region" (Gulf Business, p. 46, February 2005).

Integration: formation of the Ports Customs and Free Zone Corporation

The management of the two biggest ports was merged in 1991 to form the Dubai Ports Authority (DPA). Before the merger both ports were managed by separate entities that relied on expertise from the private sector. CSX and its daughter company SeaLand managed Jebel Ali Port, whereas Port Rashid made use of Gray MacKenzie Company. To further increase operational efficiency, DPA and JAFZA were merged to form the Ports, Customs \& Free Zone Corporation (PCFC) in 2001. Besides DPA and JAFZA, PCFC also includes the Dubai Customs Department and Dubai Ports World (see Fig. 4). This integration accommodates the supply chains' preference for a 'one-stop-one-shop' when interacting with port operators and public authorities. An additional advantage is that custom duties directly flow to the PCFC instead of the state treasury.

The influence of Sultan Ahmed Bin Sulayem on Dubai's growth is considerable, given the fact that he is also the chairman of Nakheel Properties, the state-owned property developer responsible for extraordinary developments such as "The Palms", "The World" and "Dubai Waterfront". Most of the trucks and material needed for the construction of these projects comes from abroad and as such increases the cargo throughput of the ports. In 2006, the PCFC became part of an even larger holding company named Dubai World which also includes a number of other operations, most notably, Dubai Maritime City. This organization is involved in the development of the Maritime City near Port Rashid and is planned to be cluster for all kinds of maritime-related services such as logistical advice, legal advice and ship repair.
Dominance: the growth to transnational terminal operator

By the end of the 1990s, DPA's ambitions to become a recognized global ports manager were clearly apparent. The entry of established global operators in the regional market posed considerable treats to Dubai's leading hub status. In response, DPA set up an international division in 1998, named Dubai Ports International (DPI, later to be renamed Dubai Ports World), and rapidly started to expand abroad. In 1997, DPA won a 20-year concession to manage the South Container Terminal at Jeddah Islamic Port in Saudi Arabia in partnership with local company Siyanco. One year later, DPI won a 20-year concession to manage a new container terminal at the Port of Beirut in Lebanon, only to pull back after a few years because of claimed miscalculated start-up costs and traffic volumes (UNCTAD 2003, p. 80). Nevertheless, DPI together with its sister company Jebel Ali Free Zone International continued to expand and strengthen its international position. Together they took over the management of the Port of Djibouti, its international airport, and the concession to develop and manage a free zone in the Horn of Africa. At the end of December 2005, DPI also acquired the lease concession of Aden's former PSA terminal, ${ }^{8}$ effectively eliminating the (potential) threat of Yemen's port city to Dubai's regional hub status. As such PCFC has been very active in securing terminals within its competitive port range. This is a clear dominance strategy to ensure that lines cannot bypass their facilities.

The portfolio of PCFC also includes the management of the ports of Visakhapatnam and Cochin in India. Dubai Ports entered the European market in 2004 when it won the management contract for the Port of Constanzia in Rumania. JAFZI manages the free zone of Tangiers in Morocco and of Port Klang in Malaysia. PCFC secured its first multi-port deal in December 2004 when it outbid established global terminal operators Hutchison Port Holdings and PSA to acquire the Florida-based CSX World Terminals for US $\$ 1.15$ billion. An interesting irony in this

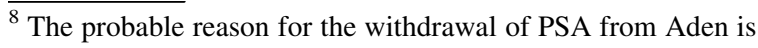
the disappointing level of productivity that can be largely attributed to terrorist's attacks in the port on the U.S.S. Cole (2000) and a CMA-CGM's oil-tanker in 2003.
} 
Fig. 4 PCFC's corporate structure. Source: Jacobs (2007a)

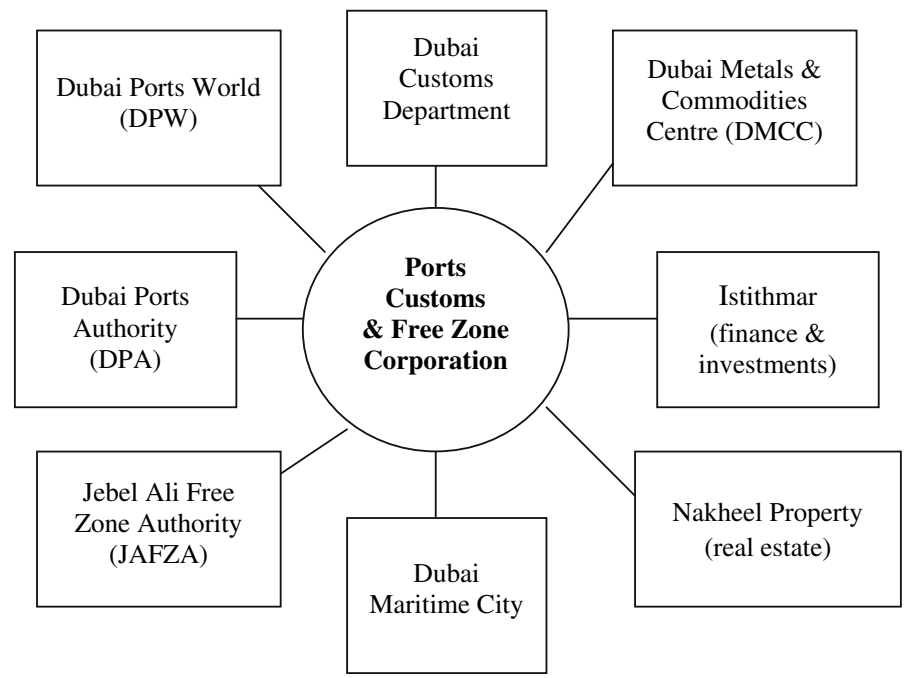

transaction is that CSX's former daughter Sea-Land used to have the management contract at Dubai's Jebel Ali Port. With the acquisition of CSXWT, Dubai Ports took over the management of nine container terminals worldwide (outside the US) with a total handling capacity of 14.6 million TEUs, including the CT3 and CT8 terminals in the world's second busiest containerport, Hong Kong (see Table 2). The acquisition provided PCFC the opportunity to capitalize on the world's fastest growing markets in China and Southeast Asia. As such, Dubai had developed from a local port authority to a global terminal operator.

About a year after this major takeover PCFC's international division, now renamed as Dubai Ports World, acquired one of the world's major stevedore companies, P\&O Ports, in a deal worth US\$ 6.8 billion. And once again, DPW managed to outbid its major competitor PSA. Much of the capital was raised through a sukuk or Islamic bond ${ }^{9}$ (worth in total US\$3.5 billion) issued by the Dubai Islamic Bank and Barclays Capital. This takeover enabled DPW to further strengthen its position in India and East Asia while penetrating the Australian and European stevedore markets (see Table 3). The takeover of P\&O Ports' portfolio in the United States (New York-New Jersey, Philadelphia, Baltimore,

\footnotetext{
${ }^{9}$ The Islamic bond market is based on Shariah, the legal code of Islam, which forbids Muslims from receiving or paying interest. In the case of sukuks, assets are sold to a specialpurpose company, which then rents them back to the user.
}

Miami, New Orleans) was however blocked by the American Congress in early March 2006, ostensibly over national security concerns.

In combination with DPA's home terminal in Dubai, PCFC was capable of handling up to 40 million TEUs in 2006, and has become the world's third largest port operator. Yet, the focus on foreign markets and other regions does not imply that PCFC will lose its roots in the Middle East. In January 2005 DPW signed a Memorandum of Understanding with the Abu Dhabi Seaport Authority and the Port of Fujairah to take over the management of their ports. Plans have also been made to expand Jebel Ali Port with three more container terminals through land reclamation, increasing its handling capacity to over 20 million TEUs by the 2020s (PCFC 2004).

\section{Conclusions}

We started the paper by posing the question what conditions the supply chain insertion, integration and dominance strategies of ports? We hypothesized that the nature of the territorial embeddedness of the port conditions the supply chain strategies of key or dominant port actors and consequently the port's embeddedness in global supply chains. For that purpose we made use of the structure of provisionapproach, and identified the place specific and path dependent physical, institutional, and political factors that underlie the territorial embeddedness which enable or constrain the supply chain related strategies 
Table 2 CSX world terminal's portfolio acquired by DPW

\begin{tabular}{llcr}
\hline CSX world terminal's global port business & & \\
\hline Country & Terminal & Shareholding (\%) & Timing \\
\hline China & Tianjin & 24.5 & Operational \\
& Yantian & 50.0 & Operational \\
& Qingdao & 26.9 & 2007 \\
& Hong Kong CT3 & 56.7 & Operational \\
& Hong Kong CT8 & 68.6 & 2005 \\
Korea & PNC Pusan & 25.0 & 2006 \\
Germany & Germersheim & 100.0 & Operational \\
Australia & Adelaide & 5.5 & Operational \\
Venezuela & Puerto Cabello & 50.0 & Operational \\
Dominican Republic & Caucedo & 35.0 & Operational \\
\hline
\end{tabular}

Source: Gulf Business, February 2005

Table 3 P\&O ports global container terminal portfolio acquired by DPW

\begin{tabular}{|c|c|c|c|c|}
\hline Country & Terminal & Shareholding $(\%)$ & Area size (ha) & Throughput 2004 (TEU) \\
\hline \multirow[t]{3}{*}{ India } & Nhava Sheva & 100 & 29 & $1,214,333$ \\
\hline & Mundra & 100 & 34 & 177,896 \\
\hline & Chennai & 75 & 13.9 & 599,980 \\
\hline Pakistan & Port Qasim & 55 & 24 & 494,535 \\
\hline Sri Lanka & Colombo & 16.25 & 20 & 146,205 \\
\hline Russia & Vostochny & 25 & 38 & 68,084 \\
\hline \multirow[t]{3}{*}{ China } & Qingdao & 29 & 146 & $1,087,358$ \\
\hline & Shekou (to be developed) & 22.5 Phase I & 51 (combined) & 474,679 \\
\hline & & 22.5 Phase II & & \\
\hline Philippines & Manila & 81.13 & 21.5 & 642,858 \\
\hline Thailand & Laem Chabung & 34.50 & 18.2 & 357,670 \\
\hline Indonesia & Surabaya & 49 & 73.8 & 528,487 \\
\hline Argentina & Rio de Plata & 53.1 & 42 & 499,278 \\
\hline Canada & Vancouver & 100 & 29 & 346,995 \\
\hline \multirow[t]{4}{*}{ Australia } & Fremantle & 100 & 13.2 & 213,908 \\
\hline & Brisbane & 100 & 24 & 352,553 \\
\hline & Sydney & 90 & 38.6 & 627,124 \\
\hline & Melbourne & 100 & 34 & 723,708 \\
\hline Mozambique & Maputo & 67 & 8 & 44,349 \\
\hline \multirow[t]{3}{*}{ France } & Le Havre & 36.67 & 48.3 & 354,478 \\
\hline & Marseille & 20.40 & 27.7 & 314,911 \\
\hline & Fos & 20.40 & 19.5 & 352,000 \\
\hline \multirow[t]{2}{*}{ Belgium } & Antwerp & 100 (Derwaide, 6th Harbour \& Hanse) & 86 (Churchill not incl.) & $1,631,929$ \\
\hline & Antwerp-Gateway (bulk) & 42.5 & 78 & N.A. \\
\hline \multirow[t]{2}{*}{ England } & Tilbury & 34 & 32 & 126,449 \\
\hline & Southampton & 51 & 76.5 & $1,441,011$ \\
\hline
\end{tabular}

Source: Website P\&O ports 
of port actors. As such, this paper makes a theoretical contribution to recent research and literature on the interface of economic and transportation geography.

The port of Dubai was introduced to enhance our empirical and conceptual understanding of the evolution of global production networks and the strategies for territorially embedded organizations to upgrade their role in these GPNs. Dubai is an important case in that its twin ports have developed into the region's major logistics and transhipment hub and, secondly, it represents a successful transformation of a local port authority into a global terminal operator under rather unique geopolitical, economic, institutional circumstances.

Through the construction of the most modern port facilities in the region, in combination with a sophisticated package of investment incentives for foreign businesses, Dubai managed to take full advantage of its strategic location as regards the burgeoning container traffic between east and west. It lured many leading manufacturers and suppliers to the port's Free Zone and, as such, has become firmly inserted within their global supply chains. With DPA in full control over the ports' land, infra-and superstructure and with its capability to mobilize resources through its position within the PCFC/Dubai World conglomerate, it can engage in strategic pricing through considerable discounts on the terminal tariffs and the custom duties that, in combination with efficient procedures and operations, allow the shipping lines and their clients to capture value. Most significant, however, is the Emirate's governance structure. The state itself resembles a multi-national corporation: it is run by an appointed, not democratically chosen, executive council; it is hardly supported by taxes, and hence is not accountable to a polity; it has strategically integrated its operations, management and responsibilities both vertically and horizontally to create both functional-economic and spatial synergy; it has a compliant, multi-national workforce; and it has spread its commercial wings across the globe. The PCFC can be regarded as the key government department or state-owned enterprise of Dubai in the Emirate's quest to become the 'Singapore of the Middle East'.

At the same time, the SOP of Dubai also restricts shipping lines in their pursuit of dedicated terminals and it constrains the local market entry of terminal operators to the benefit of DPA (cf. the downward arrows of Fig. 1). Beginning in the 1990s, these players started setting up competitive facilities across the region, and mostly in more favourable locations with respect to the major east-west ocean routes. The development of efficient mega-terminals in India and along the Arabian Sea especially, posed considerable threats to Dubai's position as transhipment hub. This incited Dubai to pursue an aggressive supply chain strategy, aimed at dominance in the regional port network; first by acquiring management contracts and operating rights across the region, later on through the corporate takeovers of CSX World Terminals and P\&O Ports. Especially the P\&O Ports-deal and the Jeddah operations provided DPW with a leading (if not dominant) position in the region, controlling at least $40-45 \%$ of its container traffic.

Looking to the future, an interesting aspect is that through its corporate takeovers, PCFC acquired operating rights in ports across the globe in which it has to operate under different conditions. As such it has become territorially embedded within other port SOPs through which it can capture value. The question arises whether this will affect the established commitments made to Dubai Ports and whether future investments will be targeted at the growth markets of India and China instead. In that respect it will be interesting to watch whether DPA will dedicate one of the planned new terminals at Jebel Ali to one of the major shipping lines. In line with this scenario is the question as to what degree DPA as the port authority can remain involved in containerhandling, or whether DPW will split off from PCFC as a separate commercial entity just as happened in the case of the former Port Authority of Singapore: PSA.

Acknowledgements The authors would like to thank two anonymous reviewers for their insightful comments on an earlier draft of this manuscript. The authors are also grateful to the American University of Sharjah for providing the facilities to carry out the fieldwork for the empirical research. The research has been supported by the NWO grant 401-01-121.

\section{References}

Ball, M. (1983). Housing policy and economic power: The political economy of owner occupation. London: Methuen.

Ball, M. (1998). Institutions in British property research: A review. Urban Studies, 35, 1501-1517. 
Broeze, F. J. A. (1999). Dubai: From creek to global port city. In: L. R. Fisher \& A. Jarvis (Eds.), Harbours and havens: Essays in port history in honour of Gordon Jackson. St. Johns.

Brooks, M. R., \& Cullinane, K. (Eds.). (2006). Devolution, port governance and performance. Elsevier.

Coe, N. M., Hess, M., Yeung, H. W. C., Dicken, P., \& Henderson, J. (2004). Globalizing' regional development: A global production networks perspective. Transactions of the Institute of British Geographers, 29, 468-484.

Cox, A., Ireland, P., Lonsdale, C., Sandersons, J., \& Watson, G. (2002). Supply chains, markets and power: Mapping supplier and buyer power regimes. London: Routledge.

Davis, M. (2006). Fear \& money in Dubai. New Left Review, 41, 47-68.

Dicken, P., Kelly, P. F., Olds, K., \& Yeung, H. W.-C. (2001). Chains and networks, territories and scales: Towards a relational framework for analysing the global economy. Global Networks, 1, 89-112.

Dicken, P. (2003). Global shift: Reshaping the global economic map in the 21st century (4th ed.). New York: Guildford.

Drewry Shipping Consultants. (2000). Middle east container ports and shipping. London.

Dubai Ports Authority (DPA). (1992). DPA handbook 1992. Dubai.

Dubai Ports Authority (DPA). (2006). DPA ports tariff 2006. Dubai.

Gore, T., \& Nicholson, D. (1991). Models of the land development process: A critical review. Environment and Planning A, 23, 705-730.

Gulf Business. (February 2005). pp. 45-48.

Hall, P. V., \& Robbins, G. (2007). Which link, which chain? Inserting Durban into global automotive supply chains. In J. Wang, D. Olivier, T. Notteboom, \& B. Slack (Eds.), Inserting port-cities in global supply chains. Aldershot: Ashgate.

Hall, P. V., Hesse, M., \& Rodrigue, J.-P. (2006). Guest editorial: Re-exploring the interface between economic and transport geography. Environment and Planning A, 38, 1401-1408.

Hall, P. V. (2003). Regional institutional convergence? Reflections from the Baltimore waterfront. Economic Geography, 79(4), 347-362.

Heaver, T., Meersman, H., Moglia F., \& van de Voorde, E. (2000). Do mergers and alliances influence European shipping and port competition. Maritime Policy \& Management, 27, 363-373.

Henderson, J., Dicken, P., Hess, M., Coe, N., \& Yeung, H. W. C. (2002). Global production networks and the analysis of economic development. Review of International Political Economy, 9, 436-464.

Hesse, M., \& Rodrigue, J.-P. (2006). Global production networks and the role of logistics and transportation. Growth and Change, 37, 499-509.

Jacobs, W. (2005). Empire along creek. The case of Dubai ports, IURPD working paper no.1. Sharjah: American University Sharjah.
Jacobs, W. (2007a). Political economy of port competition. Institutional analyses of Rotterdam, Southern California and Dubai. Nijmegen: Academic Press, Europe.

Jacobs, W. (2007b). Port competition between Los Angeles and long beach. An institutional analysis. Tijdschrift voor de Sociale en Economische Geografie, 98, 360-372.

Kaplinsky, R. (1998). Globalisation, industrialisation and sustainable growth: The pursuit of the nth rent. Institute of Development Studies, University of Sussex, IDS Discussion Paper 365.

Kaplinsky, R. (2005). Globalization, poverty and inequality. Cambridge: Polity Press.

de Langen, P. W. (2003). The performance of seaport clusters. Rotterdam: ERIM.

de Langen, P. W., \& Pallis, A. A. (2006). Analysis of the benefits of intra-port competition. International Journal of Transport Economics, 33, 69-86.

Notteboom, T. E. (2002). Consolidation and contestability in the European container handling industry. Maritime Policy and Management, 29, 257-269.

Notteboom, T. E. (2004). Container shipping and ports: An overview. Review of Network Economics, 3, 86-106.

Notteboom, T. E., \& Winkelmans, W. (2001). Structural changes in logistics: How will port authorities face the challenge? Maritime Policy \& Management, 28, 71-89.

Olivier, D, \& Slack, B. (2006). Rethinking the port. Environment and Planning A, 38, 1409-1427.

Painter, J. (2000). State and governance. In E. Sheppard \& T. J. Barnes (Eds.), A companion to economic geography (pp. 359-376). Oxford: Blackwell.

Ports Customs \& Free Zone Corporation. (2004). Cargo \& trade (issue 5). Dubai.

Robinson, R. (2002). Ports as elements in value-driven chain systems: The new paradigm. Maritime Policy \& Management, 29, 241-255.

Slack, B., Comtois, C., \& McCalla, R. (2002). Strategic alliances in the container shipping industry: A global perspective. Maritime Policy \& Management, 29, 65-76.

Slack, B. (2004). Corporate realignment and the global imperatives of container shipping. In D. Pinder \& B. Slack (Eds.), Shipping and ports in the twenty-first century (pp. 25-39). London \& New York: Routledge.

Slack, B., \& Frémont, A. (2005). Transformation of port terminal operations: From the local to the global. Transport Reviews, 25, 117-130.

Stevens, H. (1997). De Institutionele Positie van Zeehavens. Een Institutionele Positie van Zeehavens. Delft: Eburon.

Storper, M. (1997). The regional world: Territorial development in a global economy. New York: The Guilford Press.

United Nations Conference on Trade, Development (UNCTAD). (2003). Review of maritime transport 2003. New York \& Geneva: United Nations Publications.

Wang, J. J., \& Olivier, D. (2006). Port-FEZ bundles as spaces of global articulation: The case of Tianjin, China. Environment and Planning A, 38, 1487-1503.

World Bank. (2001). World Bank port reform tool kit. Module 2: The evolution of ports in a competitive world. New York. 